\title{
IOS, Company Characteristics and Board of Commissioners's Effect on Earnings Quality with Intervening Variable Earnings Persistence
}

\author{
Hidayatul Khasanah*1 and Muhammad Khafid ${ }^{2}$ \\ ${ }^{1,2}$ Accounting Department, Faculty of Economics, Universitas Negeri Semarang
}

\section{ARTICLE INFO}

\section{Article History:}

Received March 26 ${ }^{\text {th }}, 2019$

Accepted March $3^{\text {th }}, 2020$

Available March 31 th, 2020

\section{Keywords:}

board of commissioners; capital structure; earnings persistence; earnings quality; investment opportunity set; liquidity

\begin{abstract}
This study aims to examine the effect of investment opportunity set, company characteristics and board of commissioners on earnings quality with intervening variable earnings persistence. The population is manufacturing companies listed on the Indonesia Stock Exchange (IDX) in the 2015-2017 periods which consist of 156 companies. The research sample of 66 companies was obtained using purposive sampling method, so that a total of 198 units of analysis were obtained. Of the total unit analysis, outlier data was reduced by 85 data then the final total unit of analysis is 113 data. This study uses descriptive statistical analysis technique and path analysis. The results shows that IOS, board of commissioners and earnings persistence do not affect the earnings quality. Liquidity and capital structure have a significant negative effect on earnings quality. The board of commissioners does not affect the earnings persistence. The Sobel Test results show that earnings persistence is not able to mediate the influence of the board of commissioners on earnings quality. The conclusion of the study is liquidity and capital structure have a significant negative effect on earnings quality. This is a negative signal because management is considered unable to maintain the stability of the company's condition.
\end{abstract}

(C) 2020 Published by UNNES. This is an open access article under the CC BY license (http://creativecommons.org/licenses/by/4.0/)

\section{INTRODUCTION}

Financial statements are prepared and published for the benefit of the company's external parties. In addition, it is also used as a reference in measuring management performance. The financial statements must be prepared in accordance with the actual conditions of the company. In relation to financial statement information, company earnings are used as a basis for decision making and are used to measure management attainment related to company management (Demerjian et al., 2013).

In making investment decisions, investors consider quality earnings information. The earnings quality can be used as material to estimate business capacity in predicting and generating earnings in the next period. Therefore, published earnings must be relevant to the actual state of the company without any interference from anywhere (Taruno, 2013 and Kurniawan \& Khafid, 2016).

\footnotetext{
*E-mail: hidayatulkhasanah12@gmail.com

_Address: L2 Building 2nd floor, Campus Sekaran, Gunungpati, Semarang, Indonesia, 50229
}

One of the cases related to financial reporting by companies in Indonesia was one of the cases of PT Katarina Utama Tbk, which occurred in 2009 that there had been fraudulent financial statements and inflating company assets (Risdawaty \& Subowo, 2015). Katarina provides information that PT Media Intertel Graha has debts and will provide income to Katarina. But MIG confirms that this is not true. MIG has neither debt nor income to Katarina.

Some previous studies examined the earnings quality and found that it is low. The research of Marisatusholekha \& Budiono (2015) showed that earnings quality was -0.02753 , Munika et al. (2016) was 0.1364 , and Ardianti (2018) was 0.000030 . The phenomenon results in a variety of other factors that affect investors in the response to information published by the company. This makes quality is attractive to be reviewed again. Munika et al. (2016) found evidence that IOS does not affect the earnings quality. Warianto \& Rusiti (2014) and Oktarya $e t$ al. (2015) found IOS affected the earnings quality. Sukmawati et al. (2014), Nurhanifah \& Jaya (2014) and Warianto \& Rusiti (2014) found evidence of liquidity influencing earnings quality. Yushita et al. (2013) found 
that liquidity did not affect the earnings quality. Marliyana \& Khafid (2017) found that capital structure was not influential on the earnings quality. Imroatussolihah (2013) and Moradi et al. (2010) found that the capital structure influences the earnings quality. The findings of Puspitowati \& Mulya (2014) showed that the board of commissioners has no effect on the earnings quality. While the findings of Taruno (2013) and Oktaviani et al. (2015) showed that the board of commissioners influences the earnings quality. Marisatusholekha \& Budiono (2015) found that the earnings persistence did not affect the earnings quality. While the findings of Delvira \& Nelvirita (2013), Zakaria, et al. (2013), and Khafid \& Arief (2017) showed that the earnings persistence affects the earnings quality. Khafid (2012) and Kusuma \& Sadjiarto (2014) found the evidence of the influence of the board of commissioners on earnings persistence.

The purpose of the study is to empirically examine the influence of IOS, the characteristics of the company's board of commissioners on quality of life with variable intervening persistence. The originality of research is to present earnings persistence as an intervening variable to mediate the influence of the board of commissioners on the earnings qualitys. The presence of intervening variables is based on previous research which still has a weak influence between board of commissioners as an independent variable on earnings quality as the dependent variable, including Yushita $e t$ al. (2013) with the result of 0.036 and Oktaviani et al. (2015) with the result of 0.053 . In addition, the selection of earnings persistence is because the results are relatively consistent affecting earnings quality and relatively consistent between the influence of the board of commissioners on the earnings persistence. In addition, a weak direct influence between the board of commissioners on the earnings quality can provide a negative signal to investors. Management is considered to have failed to produce quality earnings. So that the presence of earnings persistence can strengthen the relationship of the board of commissioners of the company as an independent variable on earnings quality as the dependent variable.

This research uses signal theory and agency theory. Ross (1977) revealed that the gap in information acquisition between managers and investors was the cause of signal theory. The information acquisition gap is a condition when the internal party has a high level of information related to the company compared to external parties. To overcome this, the company sends a signal about the state of the company to investors. Jensen \& Meckling (1976) revealed that agency theory explained about agency and creditor agency conflicts and management and owner contracts.

IOS is a tool for companies to keep growing to achieve the company's vision and mission. According to signal theory, investors tend to positively value companies with high IOS conditions. The company does not need to worry about the availability of funds for the continuity of its business. Therefore, in the future the company is able to maximize its performance and obtain maximum earnings. So that this can encourage an increase in the earnings quality within the company. The results of the research by Warianto \& Rusiti (2014), Siahaan (2013), and Sadiah \& Priyadi (2015) show that investment opportunity sets have a positive effect on earnings quality.

\section{H1: Investment opportunity set has a positive effect on earnings quality}

Liquidity is the ability of an entity to complete its obligations. The high level of liquidity of a company, the smaller making the risk of uncollectible debt, so the higher the trust of third parties. In signal theory, an entity that has good financial capabilities reflects good prospects in the future (Nurhanifah \& Jaya, 2014). The company's ability to pay off its smooth debt can reflect the financial condition of a good company. So that the company concerned can avoid the practice of report manipulation. The results of the study of Jang et al. (2007), Setianingsih (2016), and Zein (2016) show a positive effect of liquidity on earnings quality. quality

H2: Liquidity has a positive effect on earnings

Capital structure is an indicator to determine how much debt and equity can finance assets. The greater the cost of assets using a third party loan, the higher the risk that must be borne by the company so as to provide a negative signal for investors because the role of investors is decreasing. This makes more earnings given to creditors than investors, therefore changes that occur in the capital structure will provide a signal for investors to see how the current and future financial conditions (Ghosh \& Moon, 2010 and Valipour \& Moradbeygi, 2011). The results of the study by Moradi et al. (2010), Valipour \& Moradbeygi (2011), Imroatussolihah (2013) and Dhaliwal et al. (1991) shows the influence of capital structure on earnings quality.

\section{H3: Capital Structure has a negative effect on earn- ings quality}

The board of commissioners has the duty, one of them is to monitor the performance and activities of the company's management. The board of commissioners in monitoring management activities is to make the preparation of financial statements avoid the actions of earnings manipulation and other deviations made by management. The participation of the board of commissioners in monitoring management activities is expected to be a compiled report that can be a quality report. The results of previous studies Taruno (2013), Oktaviani et al. (2015), Reskino (2015) and Buana \& Wahyudin (2016) stated that there was a positive influence of the board of commissioners on the earnings quality.

\section{H4: Board of commissioners has a positive effect on earnings quality}

Earnings persistence is used to find out the ability of an entity to maintain its continuity of earnings. The company's capacity to maintain its consistency every year is more attractive to investors. The high earnings persistence will impact on the increase in earnings quality. Therefore, information can be a positive signal 
for investors. Earnings persistence is a reflection of the earnings quality obtained as evidence that the company can maintain its earnings. The results of Delvira \& Nelvirita (2013), Zakaria et al. (2013) and Khafid \& Arief (2017) indicate the influence of earnings persistence on earnings quality.

\section{H5: Earnings persistence has a positive effect on earnings quality}

The board of commissioners as part of the elements of corporate governance has the duty, one of which is to monitor the performance of the company's management. Khafid (2012) revealed that in overseeing management activities and reporting to shareholders is a function of the presence of the board of commissioners in an entity. The board of commissioners will evaluate management performance in the internal meeting agenda. If the frequency of board of commissioners meetings decreases, it indicates that the company's performance is almost entirely entrusted by management. This can lead to modification of financial statements and other information manipulation actions. Therefore, the board of commissioners plays a role in maintaining the condition of the financial statements, especially the earnings generated to remain consistent and can be used to estimate the condition of the company further $(\mathrm{Ku}-$ suma \& Sadjiarto, 2014). Previous research by Khafid (2012), Kusuma \& Sadjiarto (2014), and Nurochman \& Solikhah (2015) showed that board of commissioners had an effect on earnings persistence.

\section{H6: The board of commissioners has a positive ef- fect on earnings persistence}

Financial reporting is one of the company's activities in which there is an important role from the board of commissioners as the company manager. With the participation of the board of commissioners in overseeing the running of the company, it can minimize the possibility of deviations made by management so that it can help create persistent earnings (Kusuma \& Sadjiarto, 2014 and Nurochman \& Solikhah, 2015). Persistent earnings can be used as a reference to see earnings obtained by an entity going forward. The high level of persistence of company earnings will result in an increase in the earnings quality of an entity (Delvira \& Nelvirita, 2013). This condition will eventually send a positive signal about the condition and performance of the company.

H7: Board of commissioners has a positive effect on the earnings quality through earnings persistence

\section{RESEARCH METHOD}

This research is quantitative with secondary annual report data and accessed through the IDX website. The research population, which is a manufacturing company that is consistently listed on the IDX for the 2015-2017 periods which consist of 156 companies. The purposive sampling technique was used to select a sample of 66 companies. The total observation was three years so that 198 units of analysis were obtained. Of them, outlier data is reduced by 85 data. Detection of the existence of outliers by determining the boundary that is equal to 2.5 . So that the analysis unit data is declared outlier if the data exceeds 2.5 or less than -2.5 $(-2.5<x<2.5)$. The details of sample selection are presented in Table 1. Explanation of research variables is presented in Table 2.

Data is collected by documentation method in the form of an annual report. The research model is analyzed by path analysis with SPSS version 23. Software analysis tool Path analysis is carried out through two steps. The first step is to regress the independent variable (board of commissioners) on the intervening variable (earnings persistence) so that the equation will be obtained as follows:

$\mathrm{PL}=\alpha+\beta_{1} \mathrm{FRI}+\mathrm{e}$

The second step is to regress the independent variables and intervening variables on the dependent variable (earnings quality) so that the equation will be obtained as follows:

$\mathrm{QE}=\alpha+\beta_{1} \mathrm{CEPBVA}+\beta_{2} \mathrm{CR}+\beta_{3} \mathrm{DAR}+\beta_{4} \mathrm{FRI}+\beta_{5} \mathrm{PL}+\mathrm{e}_{2}(2)$

Significance testing of the effect of mediation is carried out using Daniel Soper's Double Test using a 5\%

Table 1. Sample Selection Criteria

\begin{tabular}{|c|c|c|}
\hline Criteria & $\begin{array}{c}\text { Not fulfill } \\
\text { criteria }\end{array}$ & $\begin{array}{c}\text { Fulfill } \\
\text { criteria }\end{array}$ \\
\hline Manufacturing companies listed on the Stock Exchange during the period 2015-2017 & & 156 \\
\hline Consistently registered on the IDX for the period 2015-2017 & (13) & 143 \\
\hline Use of the type of rupiah in financial reporting during the $2015-2017$ period & $(28)$ & 115 \\
\hline Publish consistent and complete audited reports for the period 2015-2017 & $(16)$ & 99 \\
\hline Using the financial statements period of 12 months and ending December 31 & $(1)$ & 98 \\
\hline Provides information relating to variables & $(32)$ & 66 \\
\hline Number of sample companies used & & 66 \\
\hline Year of observation & & 3 \\
\hline Total unit analysis & & 198 \\
\hline Outlier data during the study period & & $(85)$ \\
\hline Total research data for the $2015-2017$ period & & 113 \\
\hline
\end{tabular}

Source: Secondary data processed, 2019 
significance level.

\section{RESULTS AND DISCUSSION}

Descriptive statistics testing shows that the earnings quality during the year of observation shows a fairly good average of $87.5 \%$. The average investment opportunity set shows a fairly low value of $1.2 \%$. The average company liquidity actually shows a very high value of $232 \%$ during the year of observation. While for capital structure shows an average of $43 \%$. The Financial Services Authority recommends the frequency of the board of commissioners' internal meetings to reach an average of six each year. In addition, the average persistence of manufacturing company earnings during the observation period showed a low number of $-0.7 \%$.

The results of Kolmogorov-Smirnov test (K-S) showed a significance of $0.091(0.091>0.05)$ so that the residual data is normally distributed. Then the multicollinearity test with a VIF value of $<10$ and a tolerance value $>0.01$ which is concluded that there were no multicollinearity. Next is the Durbin-Wattson test where the DW value of 2.027 is found between 1.7864 and 2.2136. It can be concluded that there is no autocorrelation. The last is the park test which the significance value is $>$ 0.05 . It is concluded that there is no heteroscedasticity.

The influence of the independent and intervening variables on the dependent variable (earnings quality) is shown in the adjusted Rsquare, which is 0.121 or $12.1 \%$. A total of $87.9 \%$ due to the existence of other independent variables. Then the results of the regression equation after the path analysis are carried out as follows:

$\mathrm{PL}=-0,042+0,006 \mathrm{FRI}$

$\mathrm{QE}=4,011+3,248 \mathrm{CEPBVA}-0,401 \mathrm{CR}$ - 5,345DAR +

0,006FRI - 0,310PL

In summary, the results of the hypotheses are presented in Table 3.

\section{Effect of Investment Opportunity Set on Earnings Quality}

Investment opportunity does not affect the earnings quality. This condition can occur because during the three years of observation, manufacturing companies showed a low difference in the book value of fixed assets to the total assets owned by $1.2 \%$. It means that the opportunity to invest in companies fixed assets of $1.2 \%$. The remaining, $98.8 \%$, is an investment opportunity that is realized in other forms such as shares. Lestari \& Wuryani (2017) state that earnings in financial statements are also used as a basis for making decisions by investors, not just focusing on high IOS values. This study is in accordance with Simamora et al. (2014), Kurnia \& Sufiyati (2015), and Munika et al., (2016).

\section{Effect of Liquidity on Earnings Quality}

Liquidity does not affect the earnings quality. $\mathrm{xThis}$ condition is proven by the average current ratio during the study period of $232 \%$. It means that the ability of current assets to finance current liabilities is more than $100 \%$ or classified as very high. It also shows an imbalance between the composition of assets and liabilities of the company so that the company's financial performance is not good (Nurhanifah \& Jaya, 2014). The inability of an entity to regulate assets smoothly reflects poor management conditions, so can encourage earnings manipulation in the company so that it can be a cause of declining earnings quality. This research is in accordance with Gharezi \& Zadeh (2013), Warianto \& Rusiti (2014) and Nurhanifah \& Jaya (2014).

\section{Effect of Capital Structure on Earnings Quality}

The capital structure influences the earnings quality. The high cost borne by the company causes an imbalance in the use of company funds. Warianto \& Rusiti (2014) states that the high level of corporate debt can cause costs to be high which then impacts on the quality of declining earnings. The larger the company's loan to external parties, the more risk of default on the company. The risk of default can lead to bankruptcy (Dhaliwal et al., 1991). This study is in accordance with Moradi et al. (2010), Imroatussolihah (2013), and Zein (2016).

\section{Effect of the Board of Commissioners on Earnings Quality}

The board of commissioners has no effect on the earnings quality. Conflicts that occur between owners and managers can be the cause of discrepancies in the results of research with agency theory. This can occur because of the ineffectiveness in the implementation of the meeting so that at least a number of internal mee-

Table 3. Hypothesis Test Results

\begin{tabular}{llccc}
\hline \multicolumn{1}{c}{ Partial/ Mediation Effect } & B & Sig. & Result \\
\hline 1 & Investment opportunity set (IOS) has a positive effect on earnings quality & 3,248 & 0,461 & Rejected \\
& $\left(\mathrm{H}_{1}\right)$ & & & \\
2 & Liquidity has a positive effect on earnings quality $\left(\mathrm{H}_{2}\right)$ & $-0,401$ & 0,042 & Rejected \\
3 & Capital Structure has a negative effect on earnings quality $\left(\mathrm{H}_{3}\right)$ & $-5,345$ & 0,000 & Accepted \\
4 & Board of commissioners has a positive effect on earnings quality $\left(\mathrm{H}_{4}\right)$ & 0,006 & 0,907 & Rejected \\
5 & Earnings persistence has a positive effect on earnings quality $\left(\mathrm{H}_{5}\right)$ & $-0,310$ & 0,144 & Rejected \\
6 & The board of commissioners has a positive effect on earnings persistence & 0,006 & 0,817 & Rejected \\
& $\left(\mathrm{H}_{6}\right)$ & & & \\
7 & Board of commissioners has a positive effect on the earnings quality through & - & 0,805 & Rejected \\
& earnings persistence $\left(\mathrm{H}_{7}\right)$ & & & \\
\hline Source: Data processed, 2019 & & &
\end{tabular}

Source: Data processed, 2019 
tings carried out will not affect the management of the company. The reason for the lack of influence of the board of commissioners on earnings quality is because the role and performance of the board of commissioners in an entity have not been optimized (Puspitowati \& Mulya, 2014). This research is in accordance with Siahaan (2013), Puspitowati \& Mulya (2014), and Budianto et al. (2018).

\section{Effect of Earnings Persistence on Earnings Quality}

Earnings persistence does not affect earnings quality. This is allegedly due to the transitory component. The transitory component is an activity whether it is a company's revenue or expenditure that comes from others beside operating, investment and funding components. Compositories are components that are not repeated. Therefore, Imroatussolihah (2013) reveals that the transitory component is seen as less relevant if it is used as a tool to predict earnings. This research is in accordance with Ashiq \& Zarowin (1992), Imroatussolihah (2013) and Marisatusholekha \& Budiono (2015).

\section{Effect of the Board of Commissioners on Earnings Persistence}

The board of commissioners does not affect the earnings persistence. It is suspected that the cause of incompatibility with agency theory is because there are still several research subjects who have a number of internal meetings that are less than the standard of financial services authorities such as PT Saranatacentral Bajatama Tbk. one time. The internal meeting standards suggested by the financial services authority are at least six times a year (Otoritas Jasa Keuangan, 2014). In addition, the existence of a board of commissioners may only be due to regulatory demands (Nurochman \& Solikhah, 2015). This research is in accordance with Nurochman \& Solikhah (2015) and Pernamasari (2018).

\section{Effect of the Board of Commissioners on Earnings Quality through Earnings Persistence}

Earnings persistence cannot mediate the influence of the board of commissioners on earnings quality based on the results of the sobel test. This is allegedly because in mediating, the earnings persistence does not have a strong information content. The low content of information in earnings persistence is allegedly due to the insignificant influence of the board of commissioners so that it does not have a strong role as a mediator. Besides that it is also suspected because of the transitory component. The transitory component is an activity whether the company's revenue or expenditure that comes from others beside operating, investment and funding components and is not recurring, so that the transitory component is less relevant to see future earnings (Imroatussolihah, 2013). This condition causes the signal given to investors to be weak due to the failure of earnings persistence as a mediating variable.

\section{CONCLUSION}

Hypothesis testing shows the results that liquidity and capital structure have a negative effect on earnings quality. In addition, the high and low of IOS, the board of commissioners, and the earnings persistence do not affect the earnings quality. The persistence of company earnings is not affected by the high and low frequency of internal board meetings. In addition, earnings persistence is not able to mediate the board of commissioners as an independent variable on earnings quality as the dependent variable.

During the three years of observation, the higher the level of liquidity and capital structure will affect the earnings quality to be low. These conditions send negative signals to investors because they assume that management cannot maintain the stability of the company's condition. The balance between the composition of assets and liabilities and the balance of roles between the parties with an interest in the company is needed so that the operations run as they should. Future research is expected to use other intervening variables such as accounting conservatism, because in analyzing financial information, investors need to apply the precautionary principle in order to avoid mistakes in analyzing information produced by the company.

\section{DAFTAR PUSTAKA}

Ardianti, R. (2018). Pengaruh Alokasi Pajak Antar Periode, Persistensi Laba, Profitabilitas, dan Likuiditas Terhadap Kualitas Laba. Jurnal Akuntansi, 6(1), 85-102.

Ashiq, A., \& Zarowin, P. (1992). The Role of Earnings levels in Annual Earnings Returns Studies. Journal of Accounting Research, 30(2), 286-296.

Buana, R., \& Wahyudin, A. (2016). The Roles of Profitability Moderating Corporate Governance on Earnings Quality. Accounting Analysis Journal, 5(3), 213-219.

Budianto, R., Samrotun, Y. C., \& Suhendro. (2018). Pengaruh Good Corporate Governance (GCG) terhadap Kualitas Laba pada Perusahaan Manufaktur yang Terdaftar di BEI 2015-2017. Prosiding Seminar Nasional: Manajemen, Akuntansi, Dan Perbankan, 1(1), 411-424.

Delvira, M., \& Nelvirita. (2013). Pengaruh Risiko Sistematik, Leverage dan Persistensi Laba Terhadap Earnings Response Coefficient (ERC). Wahana Riset Akuntansi, 1(1), 129-154.

Demerjian, P. R., Lev, B., Lewis, M. F., \& McVay, S. E. (2013). Managerial Ability and Earnings Quality. Accounting Review, 88(2), 463-498.

Dhaliwal, D. S., Lee, K. J., \& Fargher, N. L. (1991). The Association between Unexpected Earnings and Abnormal Security Returns in the Presence of Financial Leverage. Contemporary Accounting Research, 8(1), 20-41.

Gharezi, D., \& Zadeh, M. R. A. (2013). The Relationship between Earnings Quality and Risk of Liquidity in Tehran Stock Exchange. Interdisciplinary Journal of Contemporary Research in Business, 5(3), 782-805.

Ghosh, A. Al, \& Moon, D. (2010). Corporate Debt Financing and Earnings Quality, 37(5 \& 6), 538-559. https://doi. org/10.1111/j.1468-5957.2010.02194

Hossain, F., \& Ali, A. (2012). Impact of Firm Specific Factors on Capital Structure Decision : An Empirical Study of Bangladeshi Companies. International Journal of Business Research and Management, 3(4), 163-182.

Imroatussolihah, E. (2013). Pengaruh Risiko, Leverage, Peluang Pertumbuhan, Persistensi Laba, dan Kualitas Tanggung Jawab Sosial Perusahaan terhadap Earnings 
Response Coefficient pada Perusahaan High Profile. Jurnal Ilmiah Manajemen, 1(1), 1-13.

Jang, L., Sugirto, B., \& Siagian, D. (2007). Faktor-Faktor yang Mempengaruhi Kualitas Laba pada Perusahaan Manufaktur di BEJ. Jurnal Akuntabilitas, 6(2), 142-149.

Jensen, M. C., \& Meckling, W. H. (1976). Theory of the Firm : Managerial Behavior, Agency Costs and Ownership Structure, $1-78$.

Khafid, M. (2012). Pengaruh Tata Kelola Perusahaan (Corporate Governance) Dan Struktur Kepemilikan Terhadap Persistensi Laba. Jurnal Dinamika Akuntansi, 4(2), 139-148.

Khafid, M., \& Arief, S. (2017). Managerial Ownership, Corporate Governance And Earnings Quality: The Role Of Institutional Ownership As Moderating Variable. Pertanika Journal of Social Sciences and Humanities, 25(October), 241-254.

Kurnia, I., \& Sufiyati. (2015). Pengaruh Ukuran Perusahaan, Leverage, Risiko Sistematik, dan Investment Opportunity Set Terhadap Earnings Response Coefficient pada Perusahaan Manufaktur yang Terdaftar di Bursa Efek Indonesia pada Tahun 2012-2014. Jurnal Ekonomi, XX(03), 463-478.

Kurniawan, A. R., \& Khafid, M. (2016). Factors Affecting the Quality of Profit in Indonesia Banking Companies. $J u$ rnal Dinamika Akuntansi, 8(1), 30-38.

Kusuma, B., \& Sadjiarto, R. A. (2014). Analisa Pengaruh Volatilitas Arus Kas, Volatilitas Penjualan, Tingkat Hutang, Book Tax Gap, dan Tata Kelola Perusahaan Terhadap Persistensi Laba. Tax \& Accounting Review, 4(1), 1-8.

Lestari, R. D., \& Wuryani, E. (2017). Pengaruh Investment Opportunity Set (IOS), Ukuran Perusahaan dan Struktur Modal Terhadap Kualitas Laba. Jurnal Akuntansi UNESA, 5(2), 1-24.

Marisatusholekha, \& Budiono, E. (2015). Pengaruh Komisaris Independen, Reputasi Kap, Persistensi Laba, Dan Struktur Modal Terhadap Kualitas Laba. Jurnal Bina Ekonomi, 19(1), 53-70.

Marliyana, E., \& Khafid, M. (2017). Factors Affecting Earnings Quality with Capital Structure as an Intervening Variable. AAJ: Accounting Analysis Journal, 6(1), 44-51.

Mashayekhi, B., Bazaz, M., \& Bernardino, S. (2010). The Effects of Corporate Governance on Earnings Quality : Evidence from Iran. Asian Journal of Business and Accounting, 3(2).

Moghaddam, A., \& Abbaspour, N. (2017). The Effect of Leverage and Liquidity Ratios on Earnings Management and Capital of Banks Listed on the Tehran Stock Exchange. International Review of Management and Market ing, 7(4), 99-107.

Moradi, M., Salehi, M., \& Erfanian, Z. (2010). A Study of the Effect of Financial Leverage on Earnings Response Coefficient through out Income Approach: Iranian Evidence. International Review of Accounting, Banking and Finance, 2(2), 103-115.

Munika, R., Tanjung, A., \& Kamaliah. (2016). Pengaruh Kepemilikan Manajerial, Leverage dan Investment Opportunity Set Terhadap Kualitas Laba dengan Konservatisme Sebagai Variabel Moderating. Jurnal Ekonomi, 24 (4), 83-97.

Nurhanifah, Y. A., \& Jaya, T. E. (2014). Pengaruh Alokasi Pajak Antar Periode, Investment Opportunity Set dan Likuiditas Terhadap Kualitas Laba. Jurnal Ilmiah Wahana Akuntansi, 9(2), 302

Nurochman, A., \& Solikhah, B. (2015). Pengaruh Good Corporate Governance, Tingkat Hutang dan Ukuran Peru- sahaan Terhadap Persistensi Laba. Accounting Analysis Journal, 4(4), 1-9.

Oktarya, E., Syafitri, L., \& Wijaya, T. (2015). Pengaruh Pertumbuhan Laba, Investment Opportunity Set, Leverage dan Ukuran Perusahaan Terhadap Kualitas Laba. Accounting Analysis Journal, (x), 1-12.

Oktaviani, R. N, Nur, E. \& Ratnawati, V. (2015). Pengaruh Good Corporate Governance Terhadap Kualitas Laba dengan Manajemen Laba Sebagai Variabel Intervening. Jurnal Sorot, 10(1), 36-53.

Otoritas Jasa Keuangan. (2014). Roadmap tata Kelola Perusahaan Indonesia: Menuju Tata Kelola Emiten dan Perusahaan Publik yang Lebih Baik (p. 48). Retrieved from http://www.ojk.go.id/id/data-dan-statistik/ojk/ Pages/roadmap-tata-kelola-perusahaan-indonesiamenuju-tata-kelola-emiten-dan-perusahaan-publikyang-lebih-baik.aspx

Pernamasari, R. (2018). The Effect of Accrual Earnings, Corporate Governance, and Firm Size on Earnings Persistence of 100 Compass Index Companies Listed 20152016. Journal of Economics and Sustainable Development, 9(10), 196-205.

Puspitowati, N. I., \& Mulya, A. A. (2014). Pengaruh Ukuran Komite Audit, Ukuran Dewan Komisaris, Kepemilikan Manajerial, dan Kepemilikan Institusional Terhadap Kualitas Laba. Jurnal Akuntansi Dan Keuangan, 3(1), 219-239.

Reskino. (2015). The Effect of Corporate Governance on Earnings Quality with Surplus Free Cash Flow as Moderating Variable. Research Journal of Finance and Accounting, 6(4), 129-139.

Risdawaty, I. M. E., \& Subowo. (2015). Pengaruh Struktur Modal, Ukuran Perusahaan, Asimetri Informasi, dan Profitabilitas terhadap Kualitas Laba. Jurnal Dinamika Akuntansi, 7(2), 109-118.

Ross, S. A. (1977). The Determination of Financial Structure: The Incentive-Signalling Approach. The Bell Journal of Economics, 8(1), 23-40.

Sadiah, H., \& Priyadi, M. P. (2015). Pengaruh Leverage, Likuiditas, Size, Pertumbuhan Laba dan IOS terhadap Kualitas Laba. Jurnal Ilmu \& Riset Akuntansi.

Sepe, J. F., \& Spiceland, J. D. (2015). Advances in Accounting Education Article information: Advances in Accounting Education, 9, 1-15.

Setianingsih, L. (2016). Pengaruh Investment Opportunity Set, Likuiditas dan Good Corporate Governance Terhadap Kualitas Laba. Open Journal Systems, 2(2), 1-17.

Siahaan, F. O. . (2013). The Effect of Investment Opportunity Set, the Presence of Audit Committee, the Composition of Independent Commissioner, and Managerial Ownership on Profit Quality. International Journal of Business and Social Science, 4(9), 210-216.

Simamora, E., Tanjung, A. R., \& Julita. (2014). Pengaruh Investment Opportunity Set (IOS), Mekanisme Good Corporate Governance dan Reputasi KAP terhadap Kualitas laba Perusahaan. Jom Fekon, 1(2), 561-565.

Sukmawati, S. K., \& Agustina, L. (2014). Pengaruh Struktur Modal, Ukuran Perusahaan, Likuiditas dan Return on Asset terhadap Kualitas Laba. Accounting Analysis Journal, 3(1), 26-33.

Susanti. (2017). Pengaruh Leverage, Likuiditas, Ukuran Perusahaan, dan Kualitas Audit Terhadap Kualitas Informasi Laporan Keuangan. Jurnal Akuntansi Dewantara, 1(1), 85-95.

Taruno, S. A. (2013). Pengaruh Corporate Governance Terhadap Kualitas Laba : Manajemen Laba sebagai Variabel Intervening, 2(3), 323-329. 
Valipour, H., \& Moradbeygi, M. (2011). Corporate Debt Financing and Earnings Quality. Journal of Applied Finance \& Banking, 1(3), 139-157.

Warianto, P., \& Rusiti, C. (2014). Pengaruh Ukuran Perusahaan, Struktur Modal, Likuiditas, dan Investment Opportunity Set (IOS) Terhadap Kualitas Laba. Modus, 26(1), 19-32.

Yushita, A. N., Triatmoko, H., \& Rahmawati. (2013). Pengaruh Mekanisme Corporate Governance, Kualitas Auditor Eksternal, dan Likuiditas terhadap Kualitas Laba. Jurnal Economia, 9(2).

Zakaria, N. B., Isa, M. A. bin M., \& Abidin, R. A. Z. (2013). Default Risk and The Earnings Response Coefficient: Evidence from Malaysia. Journal of Basic and Applied Scientific Research, 3(6), 535-545. https://doi.org/ ISSN: 2090 - 4304

Zein, K. A. (2016). Pengaruh Pertumbuhan Laba, Struktur Modal, Likuiditas dan Komisaris Independen Terhadap Kualitas Laba dengan Komisaris Independen Dimoderasi oleh Kompetensi Komisaris Independen. Jom Fekon, 3(1), 980-992. 